\title{
ごみ燒却熱を活用した熱源ネットワークの構築に関する研究 \\ 一東京副都心エリアにおけるケーススタディー \\ RESEACH ON CONSTRUCTION OF ENERGY NETWORK USED GARBAGE INCINERATION HEAT
}

\author{
藤木洋徳 ${ }^{*}$, 曹 鳴 鳳 ${ }^{* *}$, 尾島俊 雄 ${ }^{* * *}$ \\ Hironori FUJIKI, Mingfeng CAO and Toshio OJIMA
}

\begin{abstract}
In this thesis, the current state of garbage incineration plants of 23 districts in Tokyo is studied. The use state of the garbage incineration heat was understood, $67 \%$ is generated, and the power generation efficiency of the turbogenerator is $18 \%$. The domination of the heat supply was shown, the energy reduction effect is twice, and the $\mathrm{CO}_{2}$ emission reduction effect is three times compared with the current state.

The heat supply piping network was assumed based on the result of existing research of each ministry, and the effects of energy reduction and $\mathrm{CO}_{2}$ emission reduction were examined. All the generated steam of the garbage incineration plant cannot be used effectively for the existing DHC supply area, but it has been understood that the effects of both primary energy reduction and $\mathrm{CO}_{2}$ emission reduction improve when the expansion of the supply area is assumed.
\end{abstract}

Keywords: Garbage incineration heat, District Heating and Cooling, Energy Network ごみ焼却熱、地域冷暖房、熱源ネットワーク

\section{1.はじめに}

京都議定書の発効など地球環境への刘忍は喫緊の課題で あり、エネルギー消費の多い都市部において早急な対応が 求められている。この刘応策として、「エコまちネット ワーク整備事業」注りなどを中心とした都市再生緊急整備地 域において、都市開発と一体的に熱供給インフラを整備す る等の噮境負荷の削減対策を行うことで、都市環境改善の 推進が図られている。

東京都では河川水・下水等の温度差エネルギーやごみ焼 却熱などの未利用エネルギーが多く分布している。しか し、未利用エネルギー源の多くがエネルギー需要の高い建 物高度集積地域とは離れた場所に立地しているために有効 活用出来ていない。熱供給配管網を㳎域に整備することに より、未利用エネルギー源と熱需岀発生地域との空間的な 隔たりを解消することができ、未利用エネルギ一の有効活 用が叮能となる(1-う)。

これまで、清掃 $\mathrm{I}$ 場を熱源とする地域熱供給の可能性の

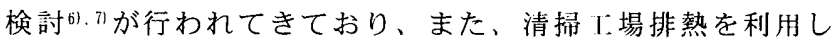

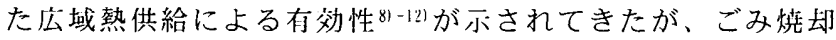
熱の発生特性、利用状濯や清掃 $\mathrm{l}$ : 場の発電効率について、
奏績值に基づき詳細に検討されている研究報告例は少な い。

本研究では、まず東京都23区における近年のごみ谠却熱 の特性、発電の垷状についての態調杳を行った後に垁績 值を用いて、熱供給の優位性を明らかにする。その後、各

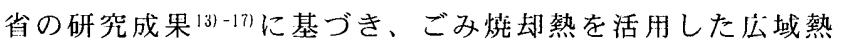
供給配管網（以降熱源ネットワーク）を仮定し、熱源ネッ トワークを整備することによるエネルギー削減効果、C02 削減効果を検討する。尚、本研究における熱源ネットワー クとは清挦丁場から熱源プラントまでを直接慗ぐ導管と定 義する。

\section{2. 東京都23区における清掃工場の現状調查}

東京二十三区清摛一部事務組合へヒアリングを行い、束 京都23区における各清掃工場の詳細概要（建築概要、設備 概要等)、ごみ燒却量、蒸気発生量、発電電力量、メンテ ナンススケジュール等のデータを入手した。

その実態の把握及びデータベースの作成、ごみ焫却熱を 熱供給することの優位性の研究を行った。尚、今问入手し たデータは全て2003年度の尖績值である。

\footnotetext{
* 大阪ガス侏

(当時、早稲田大学大学院修士課程)

** 早稲田大学大学院理工学研究科 博士課程

*** 早稲田大学理工学部建築学科 教授. 工博
}

Osaka Gas Co., Ltd.

(Graduate School, Waseda Univ.)

Ph. D. Student, Graduate School of Science and Engineering, Waseda Univ.

Prof., Dept. of Archtecture, Waseda University, Dr. Eng. 


\section{1 東京都23区における清掃工場の概要}

2006年2月現在、東京都 23 区では22筒所の清接 I場が建設 されており、19简所の清掃「場が稼働中である。他の3箅 所の内、2箇所（品川、葛飾）がプラント更新中、1䈯所 （世田谷）が建替中により運転を停止している。各清掃「 場の概要を表 1 に示す ${ }^{181.19)}$ 。これら全ての清㑇I場には発電 設備が設けられており、ごみ焼却熱を利用した発電が行わ れている。また、現在稼働中である清掃 I場 19箇所中、15 籄所において高温水、蒸気等を熱媒体とした熱供給がされ ており、その内、有明清掃 $\mathrm{L}$ 場、光が丘清掃亡場では地域 冷暖房への熱売却を行っている。

\section{2 東京都の焼却排熱の利用方法}

東京都のごみ焼却排熱201の利用方法を大きく分類すると 次のようになる。

(1)ごみ発電

(2)「場に隣接した地元還元施設への熱供給 (無料で提供している)

(3) 地域冷暖房（熱を有料で供給している）

(4)清掃工場内で使用する熱（冷暖房、給湯ほか）

(5)焼却に必要な熱源（燃焼用空気予熱器の熱源ほか）

2.3 清掃工場におけるごみ焼却の特性

（1）年間・月別ごみ焼却量

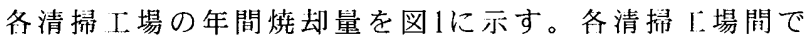

\section{表1 東京都23区における清掃工場の概要}

\begin{tabular}{|c|c|c|c|c|c|c|c|}
\hline & 点杸 & $I$ & 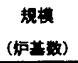 & 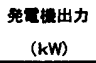 & 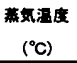 & 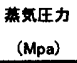 & 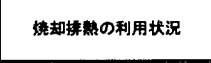 \\
\hline & 潵谷 & 2001 年7月 & $\begin{array}{l}200 \mathrm{t} / 24 \mathrm{~h} \\
(200 \mathrm{t} \times 1)\end{array}$ & 4,200 & 400 & 4.10 & 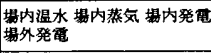 \\
\hline & 光が丘 & 1983年9月 & $\begin{array}{l}300 \mathrm{t} / 24 \mathrm{~h} \\
(150 \mathrm{t} \times 2)\end{array}$ & 4,000 & 280 & 2.21 & 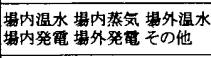 \\
\hline & 多度川 & 2003年6月 & $\begin{array}{l}300 \mathrm{t} / 24 \mathrm{~h} \\
(150 \mathrm{t} \times 2)\end{array}$ & 6,400 & 400 & 4.39 & 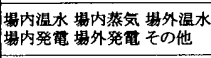 \\
\hline & 足立 & 2005年3月 & $\begin{array}{l}700 \mathrm{t} / 24 \mathrm{~h} \\
(350 \mathrm{t} \times 2)\end{array}$ & 8,750 & 400 & 4.08 & 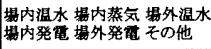 \\
\hline & 有明 & 1995年12月 & $\begin{array}{l}400 \mathrm{t} / 24 \mathrm{~h} \\
(200 \mathrm{t} \times 2)\end{array}$ & 5,600 & 300 & 2.75 & 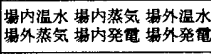 \\
\hline & 䓙島 & 1999年6月 & $\begin{array}{l}400 \mathrm{t} / 24 \mathrm{~h} \\
(200 \mathrm{t} \times 2)\end{array}$ & 7,800 & 300 & 3.14 & 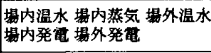 \\
\hline & 林馬 & 1992年9月 & $\begin{array}{l}600 \mathrm{t} / 24 \mathrm{~h} \\
(300 \mathrm{t} \times 2)\end{array}$ & 1,500 & 214 & 1.72 & 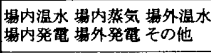 \\
\hline & 杉亚 & 1982年12月 & $\begin{array}{l}900 \mathrm{t} / 24 \mathrm{~h} \\
(300 \mathrm{t} \times 3)\end{array}$ & 6,000 & 290 & 2.28 & 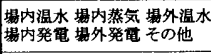 \\
\hline 稳 & 大田第一 & 1990年3月 & $\begin{array}{l}600 \mathrm{t} / 24 \mathrm{~h} \\
(200 \mathrm{t} \times 3)\end{array}$ & 12,000 & 300 & 2.75 & 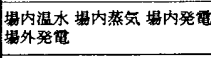 \\
\hline & 大田第二 & 1990年3月 & $\begin{array}{l}600 \mathrm{t} / 24 \mathrm{~h} \\
(200 \mathrm{t} \times 3)\end{array}$ & 15,000 & 300 & 2.65 & 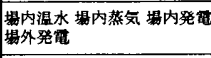 \\
\hline m & 目重 & 1991年3月 & $\begin{array}{l}600 \mathrm{t} / 24 \mathrm{~h} \\
(300 \mathrm{t} \times 2)\end{array}$ & 11,000 & 300 & 2.65 & 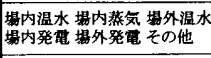 \\
\hline & 千壦 & 1996年3月 & $\begin{array}{l}600 t / 24 \mathrm{~h} \\
(600 \mathrm{t} \times \mathrm{l})\end{array}$ & 12,000 & 300 & 3.04 & 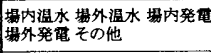 \\
\hline & 江F川 & 1997年1月 & $\begin{array}{l}600 \mathrm{t} / 24 \mathrm{~h} \\
(300 \mathrm{t} \times 2)\end{array}$ & 12,300 & 300 & 2.84 & 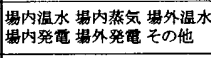 \\
\hline & 量田 & 1998年1月 & $\begin{array}{l}600 \mathrm{t} / 24 \mathrm{~h} \\
(600 \mathrm{t} \times 1)\end{array}$ & 13,000 & 300 & 2.65 & 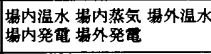 \\
\hline & 北 & 1998年3月 & $\begin{array}{l}600 \mathrm{t} / 24 \mathrm{~h} \\
(600 \mathrm{t} \times 1)\end{array}$ & 11,500 & 280 & 2.75 & 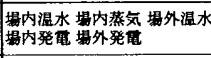 \\
\hline & 溇 & 1999年1月 & $\begin{array}{l}900 \mathrm{t} / 24 \mathrm{~h} \\
(300 \mathrm{t} \times 3)\end{array}$ & 22,000 & 300 & 2.79 & 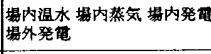 \\
\hline & 中央 & 2001年7月 & $\begin{array}{l}600 \mathrm{t} / 24 \mathrm{~h} \\
(300 \mathrm{t} \times 2)\end{array}$ & 15,000 & 400 & 3.95 & $\begin{array}{l}\text { 境内温水場内蒸気 嚗外温水 } \\
\end{array}$ \\
\hline & 揤棈 & 2002年11月 & $\begin{array}{l}600 \mathrm{t} / 24 \mathrm{~h} \\
(300 \mathrm{t} \times 2) \\
\end{array}$ & 13,200 & 400 & 3.89 & 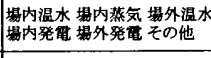 \\
\hline & 敷江菓 & 1998年 9 月 & $\begin{array}{l}1800 \mathrm{t} / 24 \mathrm{~h} \\
(600 \mathrm{t} \times 3) \\
\end{array}$ & 50,000 & 300 & 2.75 & \begin{tabular}{|l} 
\\
\\
\\
\end{tabular} \\
\hline $\mathbf{T}$ & 品川 & 2006年3月 & $\begin{array}{l}600 \mathrm{t} / 24 \mathrm{~h} \\
(200 \mathrm{t} \times 3)\end{array}$ & 15,000 & & & 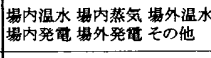 \\
\hline to & 慗第 & 2006年12月 & $\begin{array}{l}500 \mathrm{t} / 24 \mathrm{~h} \\
(250 \mathrm{t} \times 2) \\
\end{array}$ & 13,500 & 216 & 2.06 & 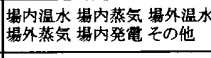 \\
\hline t) & 世田谷 & 2007年12月 & $\begin{array}{l}300 \mathrm{t} / 24 \mathrm{~h} \\
(150 \mathrm{t} \times 2)\end{array}$ & 15,000 & & & 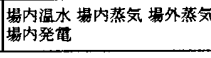 \\
\hline
\end{tabular}

年問ごみ焼却量が人きくばらついていることが分かる。ま た、各清捗厂。場の月別ごみ焼却量を図2、年間焼却量に対 する月別焼却量の割合（月別ごみ焼却量パターン）を図 3 に示す。清掃工場の烧却量は各月で大きく変動しており、 その変動パターンが冬清排「場で大きく異なっていること が分かる。これは、清撫「場で行われる每年数十日閶の焼 却炉のメンテナンスによるものである。束京都23区全体の ごみ処分能力が極端に低下しないよう、各清掃L.場で翼な

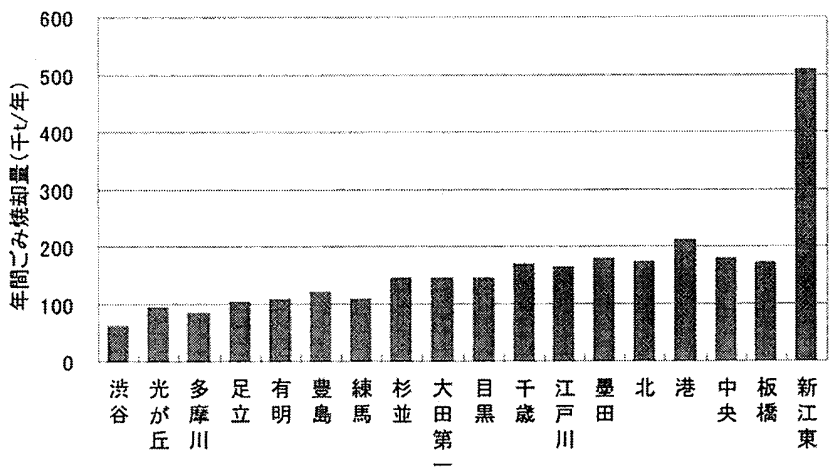

図1各清掃工場の年間ごみ焼却量

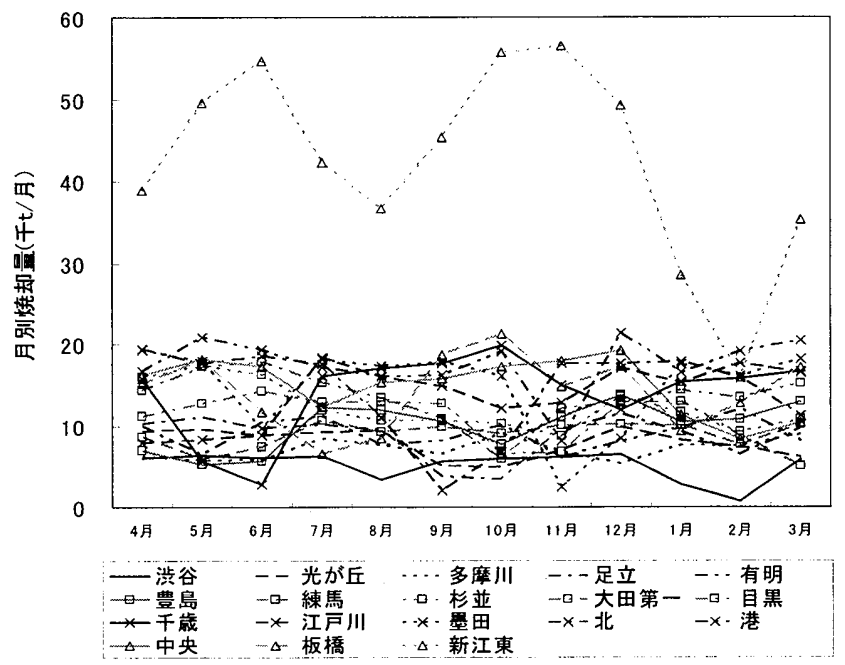

図2 各清掃工場の月別ごみ焼却量

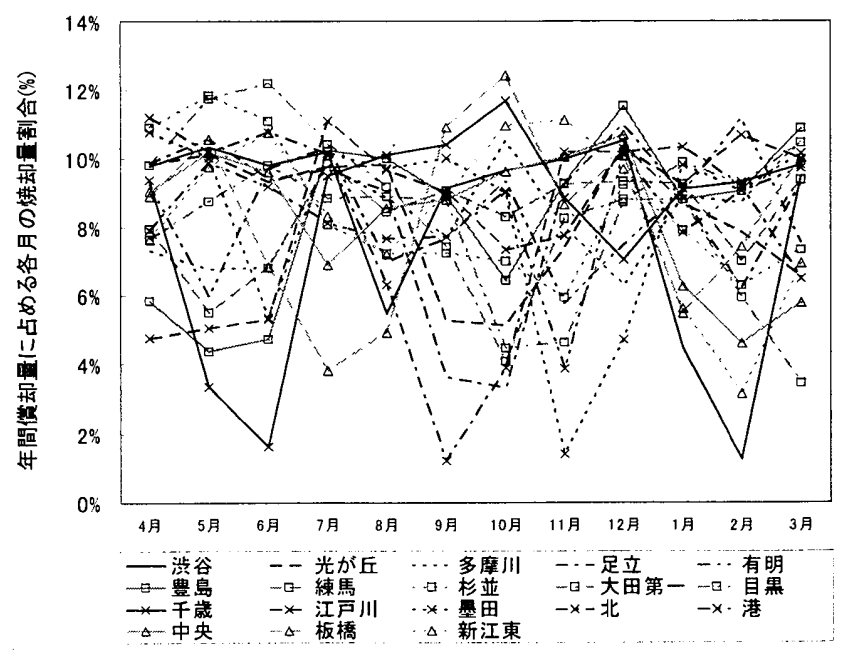

図3 各清掃工場の月別焼却量パターン 


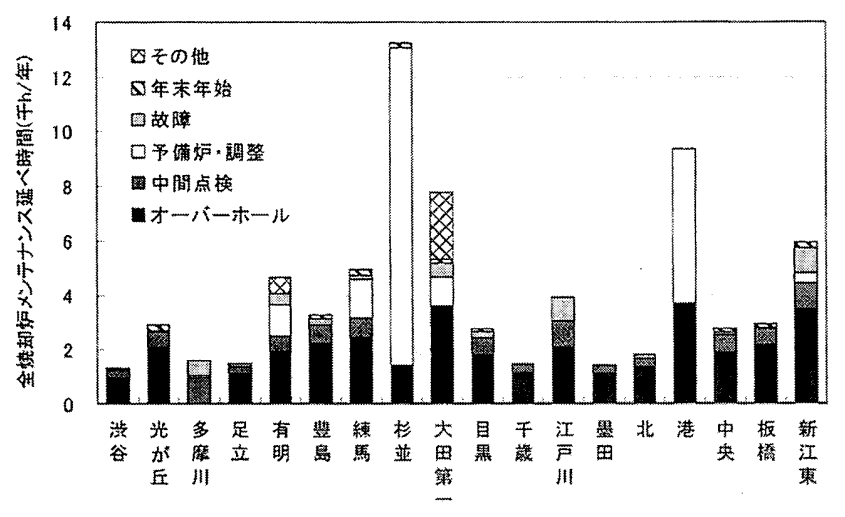

図4全焼却炉のメンテナンス延ベ時間の内訳

るメンテナンススケジュールが組まれているため、各清掃 [場の変動パターンが大きく異なっている。

（2）焼却炉のメンテナンス

各清掃亡場における全焼却炬のメンテナンス延べ時閒の 内訳を図4に示す。各焼却炉は毎年オーバーホールが行わ れ、定期的な中間点検や予備炉が設置されている。凡例に 表示している調整期閒とは、ごみ不足による調整期間を意 味している。内訳を見てみると、オーバーホール、中開点 検、予備炉調整がメンテナンス期閂の大部分を占めてい る。次いで故障による休炉期閒が多く、想定外のトラブル により年間数日の休炉期開が発生している。ごみ焼却熱を 活用した地域熱供給を行う際に、このような予想外のトラ ブルが発生すると熟供給事業に大きな支障となる。1 䈏所 の清揞 $\mathrm{I}$ 場ではなく、複数の清㨎 $\mathrm{T}$ 場を組み込んだ熱供給 システムを棈築することが、リスクの回避策として有効で ある。

また、炉数別運転日数注2を図5に示す。各清掃「場では安 定したごみ処理を行うため、企炉停止期間を少なくする必 㟶がある。そのため各焼却炉のメンテナンス期開がずれる ように設定されており、図5のように全炉停止期間は短く なっている。その中、DHCへ熱供給している清揥 $\mathrm{T}$ 場で は、熱供給事業への支障を極力避けるため、中間期に集中 してメンテナンス期開が設けられている。

\section{4 清掃工場における蒸気発生量及び発電量の現状 \\ （1）清掃工場における蒸気発生量}

各清掃厂場の蒸父発生量、タービン投入蒸気量、発電電 力显の奏績值を表 2 に示す。全発生蒸気量のうち、平均 $67 \%$ がタービンへ投入され、発電し、その効率は平均18\%であ る。発生蒸気全体の利用率洼31 は12.6\%にすぎない。

\section{（2）清掃工場における発電量}

現在稼働中の束京都23区の清披て場が企て発電設備を有 しており、所内利用分電力および売電分電力を発電してい る。また、現在プラント更新中および建替中の清舅〔場に 関しても、リニューアル後に発電設備を導入することが決 定している。

表3は各清捎上場の年閶䉓力利用状況を示す。発電した 電力を所内で消費しきれず、一般電気事業者への売電を

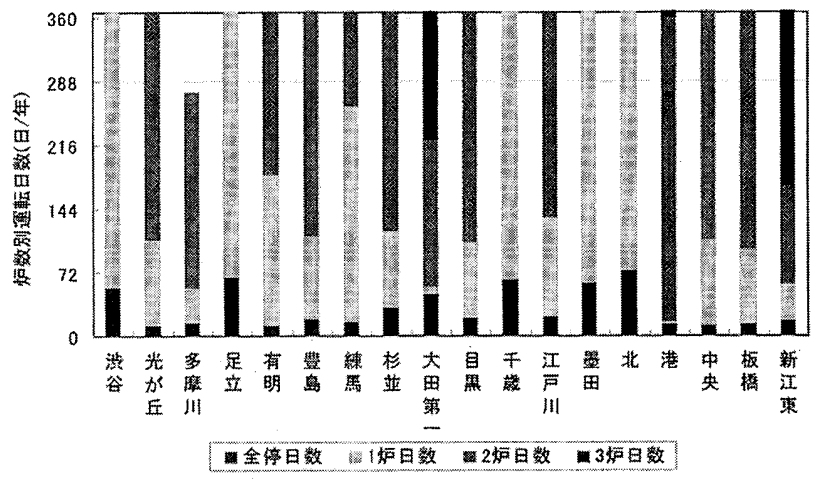

図5全焼却炉年間炉数別運転日数注2?

表2 各清掃工場における年間発生蒸気利用状況

\begin{tabular}{|c|c|c|c|c|c|}
\hline \multirow[t]{2}{*}{ 清掃工場 } & $\begin{array}{l}\text { 全蒸気 } \\
\text { 発生量 }\end{array}$ & $\begin{array}{c}\text { タ-ビ”投入 } \\
\text { 蒸気量 }\end{array}$ & 発電電力量 & $\begin{array}{c}\text { 夕ービ発電 } \\
\text { 效率 }\end{array}$ & $\begin{array}{l}\text { 全発生蒸気 } \\
\text { 利用率注3) }\end{array}$ \\
\hline & ( $t$ / 年) & （t／年） & (kWh /年) & (\%) & $(\%)$ \\
\hline 渋谷 & 171,412 & 116,003 & $23,213,600$ & $22 \%$ & $13.1 \%$ \\
\hline 光が丘 & 240,535 & 139,057 & $18,491,930$ & $16 \%$ & $9.5 \%$ \\
\hline 多摩川 & 189,221 & 129,629 & $26,182,840$ & $23 \%$ & $13.6 \%$ \\
\hline 足立 & 289,479 & 196.197 & $33,954,920$ & $20 \%$ & $16.3 \%$ \\
\hline 有明 & 388,746 & 287,801 & $16,025,210$ & $7 \%$ & $4.9 \%$ \\
\hline 豊島 & 342,843 & 264,809 & $36,067,730$ & $16 \%$ & $12.4 \%$ \\
\hline 練馬 & 312,818 & 175,398 & $11,871,680$ & $9 \%$ & $4.4 \%$ \\
\hline 杉亚 & 356,595 & 178,849 & $26,978,400$ & $18 \%$ & $8.5 \%$ \\
\hline 大田第一 & 489,812 & 104,833 & $15,259,922$ & $17 \%$ & $13.0 \%$ \\
\hline 大田第二 & 423,903 & 425,693 & $69,226,900$ & $20 \%$ & $12.0 \%$ \\
\hline 目黒 & 468,523 & 282,294 & $42,381,002$ & $18 \%$ & $11.5 \%$ \\
\hline 千歳 & 545,143 & 384,116 & $61,932,370$ & $19 \%$ & $14.5 \%$ \\
\hline 江戸川 & 484,667 & 314,552 & $55,916,674$ & $21 \%$ & $15.3 \%$ \\
\hline 墨田 & 596,710 & 404,142 & $67,826,930$ & $20 \%$ & $16.3 \%$ \\
\hline 北 & 539,320 & 325,313 & $52,178,430$ & $19 \%$ & $13.1 \%$ \\
\hline 港 & 698,987 & 480,831 & $79,991,700$ & $20 \%$ & $15.3 \%$ \\
\hline 中央 & 562,195 & 400,326 & $77,632,110$ & $22 \%$ & $16.1 \%$ \\
\hline 板橋 & 532,574 & 340.340 & $69,536,160$ & $23 \%$ & $15.0 \%$ \\
\hline 新江東 & $1,702,361$ & $1,290,923$ & $204,480,168$ & $19 \%$ & $15.5 \%$ \\
\hline 合計 (平均) & $9,335,844$ & $6,241,106$ & $989,148,676$ & $18 \%$ & $12.6 \%$ \\
\hline
\end{tabular}

表 3 各清掃工場における年間電力利用状況

\begin{tabular}{|c|c|c|c|}
\hline \multirow{2}{*}{ 清掃工場 } & 自家用電力吾 (発電分) & 売電電力㽬 (発電分) & 受電電力量 \\
\hline & (kWh/年) & (kWh/年) & (kWh/年) \\
\hline 涉谷 & $13,772,320$ & $9,441,280$ & $1,272,400$ \\
\hline 光が丘 & $16,038,950$ & $2,452,980$ & $1,771,200$ \\
\hline 多摩川 & $22,231.540$ & $3,951,300$ & $3,759,820$ \\
\hline 足立 & $15,604,520$ & $18,350,400$ & $3,247,880$ \\
\hline 有明 & $15,559,850$ & 465,360 & 10.649 .680 \\
\hline 豊島 & $25,984,778$ & $10,082,952$ & $1,513,440$ \\
\hline 練馬 & $10,232,408$ & $1,639,272$ & 438,168 \\
\hline 杉並 & $18.467,760$ & $8,510,640$ & $3,481,560$ \\
\hline 大田第一・二 & $83,936,622$ & 550,200 & $15,989,600$ \\
\hline 目黒 & $22,396,202$ & $19,984,800$ & 777,840 \\
\hline 千歳 & $16,835,410$ & $45,096,960$ & $1.729,200$ \\
\hline 江戸川 & $24,423,394$ & $31,493,280$ & $1.036,800$ \\
\hline 墨田 & 22.376 .130 & $45,450,800$ & $2,214,800$ \\
\hline 北 & $28,324,430$ & $23,854,000$ & $3,071,600$ \\
\hline 港 & $37,338,012$ & $42,653,688$ & $1,014,900$ \\
\hline 中央 & $29,348.270$ & $48,283,840$ & 496,800 \\
\hline 板橋 & $66,033,160$ & $3,503,000$ & $15,590,800$ \\
\hline 新江東 & 79.143 .768 & $125,336,400$ & $2,536.800$ \\
\hline 合 計 & $548,047,524$ & $441,101,152$ & $70,593.288$ \\
\hline
\end{tabular}


行っている。所内利用電力量は平均で約 $55 \%$ 、売電電力量 は平均で約 $45 \%$ ある。

\section{5 発生蒸気を熱供給することの優位性}

清掃「場における発電量、蒸父発生量、蒸気エンタルピ などのデータを用いて発生蒸気を熱供給することの優位性 を示す。尚、本研究では、代替発電所として、エネルギー 削減効果の算出の際には火力発電所、 $\mathrm{C}_{2}$ 削減効果の算出の 際には全電源及び火力発電所を想定している注り。

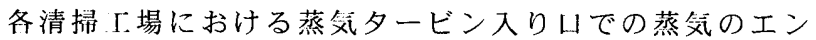
タルピは、稼働中の清掃「場（2006年2月）、蒸気 $1 \mathrm{~kg}$ あた り $675 \mathrm{kcal} \sim 770 \mathrm{kcal}$ で平均 $727 \mathrm{kcal}$ 、殆ど一定である。

発生蒸気を発電に利用した場合、清掃 $\mathrm{L}$ 場のボイラによ り製造される蒸気 $1 \mathrm{t}$ を清掃 $\mathrm{l}$ 場のタービンへ投入すること で、東京都区部清掃 $\mathrm{l}$ : 場の平均で、 $156 \mathrm{kWh}$ 電力が発電で きる。仮に $156 \mathrm{kWh}$ の電力を一般電気事業者の保有する火力 発電所で発電したと想定すると、その際に必要な一次エネ ルギーはHHV基準で $1.54 \mathrm{GJ}$ となり、発電に伴い排出される $\mathrm{CO}_{2}$ は $108 \mathrm{~kg}-\mathrm{CO}_{2}$ 、全電源平均で $59 \mathrm{~kg}-\mathrm{C0}_{2}$ となる。すなわち、 現状の清掃 I場にて発生する蒸父 $1 \mathrm{t}$ あたりの投入一次エネ ルギー削減量は $1.54 \mathrm{GJ}$ であり、蒸気 $1 \mathrm{t}$ あたりのC 0 , 削減量 は、火力と比較した場合 $108 \mathrm{~kg}-\mathrm{CO}_{2}$ 、全電源と比較した場合 $59 \mathrm{~kg}-\mathrm{CO}_{2}$ とみなすことが出来る。

清掃I場から発電せずにDHCプラントへ熱を供給した場合 を想定する。蒸枸1 tによりDHCプラント注5 は冷熱を2. $21 \mathrm{GJ}$ 、 温熱を1.12GJ供給することが可能となる。そこで、仮にこ の冷熱、温熱をDHCプラントで製造した場合、必要な投入 一次エネルギー(都市ガス)はHHV基準で3.87GJであり、それ に伴い排出されるC0, は $198 \mathrm{~kg}-\mathrm{CO}_{2}$ てである。清掃 [場にて発生 する蒸気 $1 \mathrm{t}$ あたりの投入一次エネルギ一削減量を $3.87 \mathrm{GJ}$ 、 蒸気 $1 \mathrm{t}$ あたりのCO削減量を $198 \mathrm{~kg}-\mathrm{CO}_{2}$, とみなすことが出来 る。

以 $\mathrm{t}$ のことから、熱供給として活用した場合、発電に比 して約2.5倍の投入一次エネルギー削隇㕮果があり、火力 平均 $\mathrm{C} 0$, 排出係数を用いた場合約 $\mathrm{l} .8$ 倍、全電源平均 $\mathrm{C} 0$ ，排出 係数を用いた場合約 3.4 倍の $\mathrm{C}_{2}$ 削減効果がある。

各清掃工場に対して、発生蒸気をタービンへ投入し発電 を行ったケース（現状）とその蒸氛分全てを熱供給した ケース（提案）を想定し、両ケースにおける投入一次エネ ルギー削減量と $\mathrm{C}_{2}$ 削隇量を示したのが図6、図7である。試 算した結果、投入一次エネルギ一削減効果は、現状と比較 して、熱供給した方が2.0倍の効果を示す絓果となった （全清掃 ᄃ場平均）。また、 $\mathrm{C} 0$,削減効果は、火力平均 $\mathrm{C} 0$, 排 出原単位を用いると現状の 1.5 倍の削減効果があり、全電 源平均 $\mathrm{C}_{2}$, 排出原単位を用いると現状の 3.0 倍の効果を示す

（全清㜔 $\mathrm{J}$ 場平均）。発電効率の羊いなどにより备清掃 $\mathrm{T}$ 場でばらつきはあるものの、全ての清排「場において、発 生蒸父を発電に利用するよりも熱供給に利用できれば一次 エネルギー削減荲、CO，削減量ともに晌：することが分かっ た。

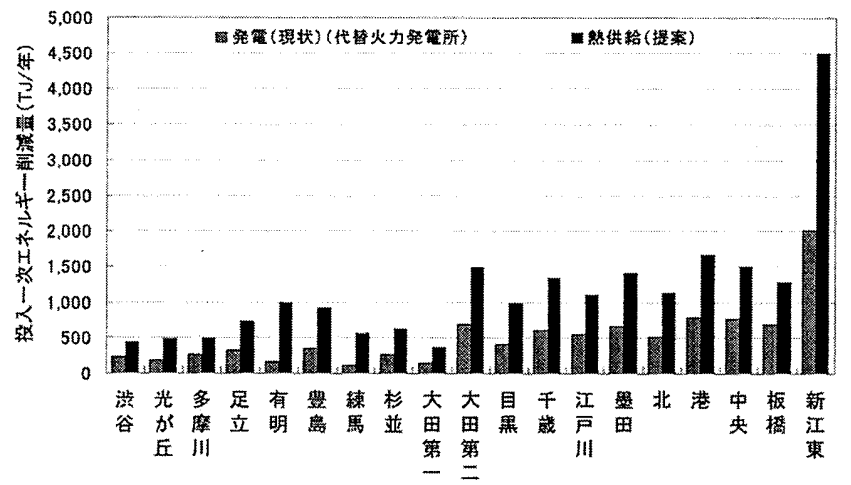

図6 熱供給した場合と発電した場合の一次I神ギ削減量

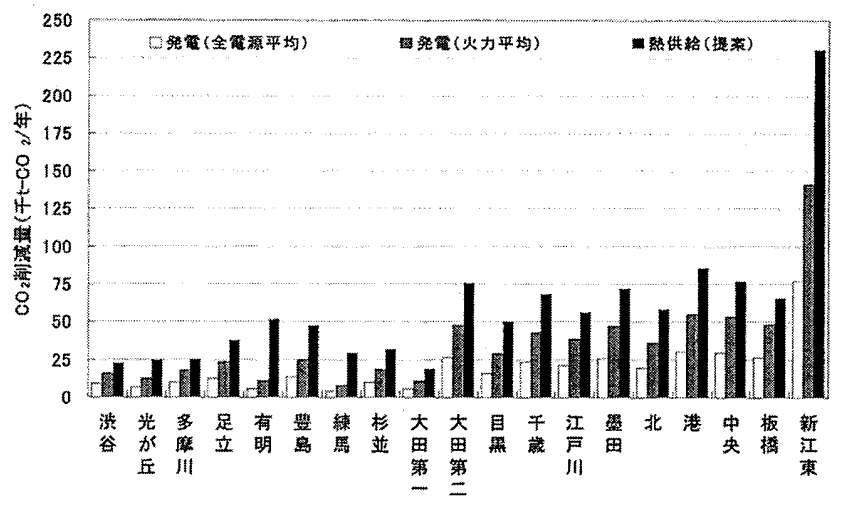

図7熱供給した場合と発電した場合のC02削減量

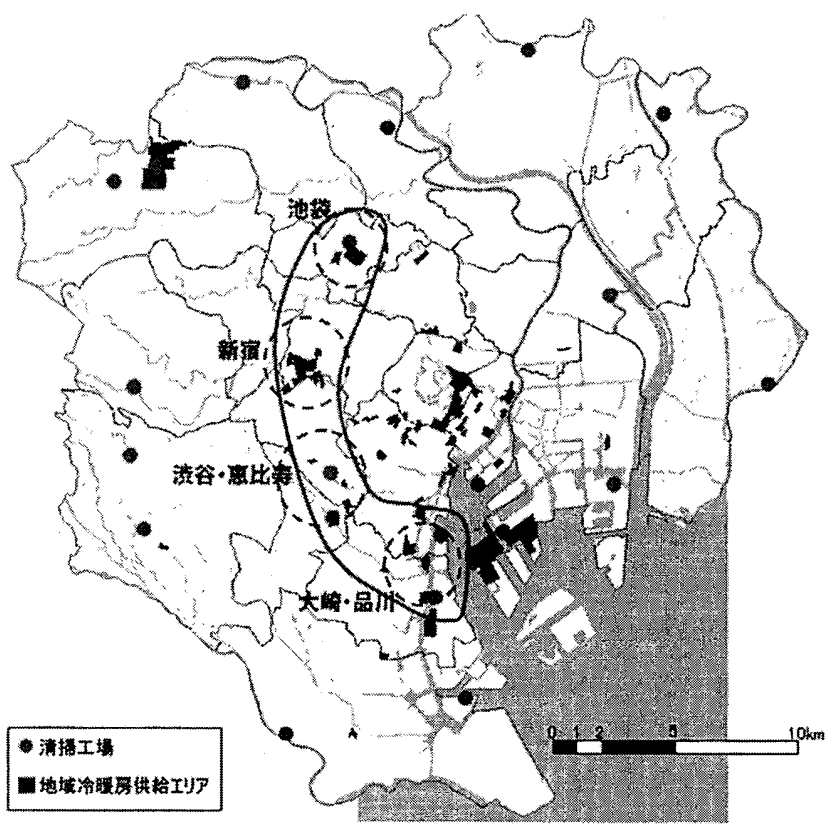

図8＼cjkstart東京都区部における清掃工場・DHCの分布

\section{3. 熱源ネットワークの検討}

清揞 $\mathrm{I}$. 場の排熱を直接DHCに利用できれば、少エネル ギ一、 $\mathrm{CO}_{2}$ 削隇に大きく奇与することが分かったので、その 问能性を以トにに検刢する。

\section{1 熱源ネットワークの仮定}

図8に束京都区部における清掃 1 場と既存DHCプラントの 


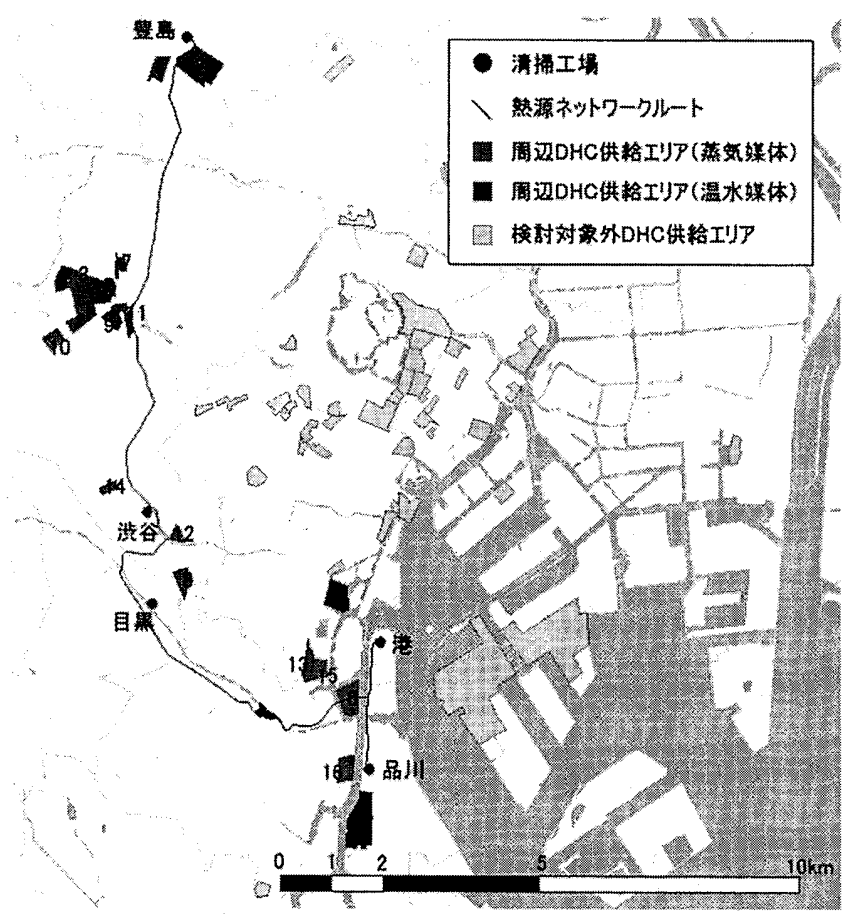

図9仮定した熱源ネットワーク

分布をホす。ネットワーク導管敖設費朋や導管内の熱損失 21)を考慮し、既存DHCプラントに隣接している清掃 ᄃ場を選 定する。ネットワーク導管のルートは、エコまちネット ワーク整備事業及び冬省研究会(3)-17)の研究成果に基づき仮 定する（図9）。熱源ネットワークの対象とする清掃 1 . 場 は、豊島、橴谷、日黒、港、品川清掃 I場の5笝所であ る。

\section{2 供給熱媒体}

図9に伋定したネットワーク周辺の既存DHCプラント16籄 所（図中番号 1～16）を表示している。そのうち、蒸父を 媒体として温熱供給が行われているプラントが12箇所、温 水を媒体として温熱供給が行われているプラントが4籄 所、温水と蒸気の2つを媒体として温熱供給が行われてい るプラントが4䇫所存在する。この周辺地区におけるDHCの 年開温水肘売量の合計が 161 ( TJ/年) であり、年問蒸父販売 量の合計が、1, 548 (TJ / 年) 221.231である。つまり、このエリ アにおけるDHCの内 $90 \%$ 以上が蒸父供給方式である。

\section{3 供給先蒸気需要量と清掃工場蒸気発生量}

供給先である既存DHCプラントの蒸気需要量を把握するた め、冬DHCプラントヘアンケート及びヒアリング調查を行 い、取得したデータ（2004年度の尖績值）を表4に示す。

既你DHCプラントを熱源ネットワークの供給先として、仮 に清掃「場の発生蒸父を熱供給する場合、図10のように、 DHCの蒸父需要量に刘する清掊工場の発生蒸父を多く、ご み焯却熱を有㕮に使いきることができない。そこで清摛 $\mathrm{I}$ 場の発生蒸父を有効に使うためには供給先を増やし、熱負 荷を増人させる必要がある。

熱源ネットワークは計画段階から運用段階に至るまで、 $1 、 2$ 年という短い期開ではなく、10年以1:の長期を有す
表 4 各DHCプラントの取得データ概要

\begin{tabular}{|c|c|c|c|c|c|c|c|c|c|c|}
\hline \multirow[b]{2}{*}{ No. } & \multirow{2}{*}{ 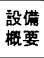 } & \multicolumn{4}{|c|}{ 製造然量 } & \multicolumn{4}{|c|}{ 燃料使用量 } & \multirow{2}{*}{ 呰 考 } \\
\hline & & 年間 & 月別 & 日別 & 時刻別 & 年間 & 月別 & 日别 & 時刻別 & \\
\hline 1 & 0 & 0 & 0 & & 0 & $\mathrm{O}$ & $\mathrm{O}$ & & \begin{tabular}{l|l}
0 & $B$ \\
\end{tabular} & 時刻別デ一夕は季節別の特定期間のみ \\
\hline 2 & 0 & 0 & 0 & 0 & 0 & 0 & 0 & 0 & 0 & 時刻別 テー一夕は8760時間分 \\
\hline 3 & 0 & 0 & 0 & & 0 & $\mathrm{O}$ & 0 & & 0 & 時刻別データは季竽別の特定期間のみ \\
\hline 4 & 0 & 0 & & & & 0 & & & & \\
\hline 5 & 0 & 0 & 0 & & 0 & 0 & 0 & & 0 & 時刻別データは季箅別の特定期間のみ \\
\hline 6 & 0 & 0 & 0 & 0 & 0 & 0 & 0 & O & 0 & 時刻別デー夕|外8760時間分 \\
\hline 7 & 0 & $\mathrm{O}$ & 0 & & 0 & 0 & 0 & & 0 & 時刻別でータは季節別の特定期間のみ \\
\hline 8 & $\mathrm{O}$ & 0 & 0 & 0 & 0 & 0 & 0 & O & 0 & 時刻別テーー夕は季節別の特定期間のみ \\
\hline 9 & 0 & 0 & 0 & & 0 & 0 & 0 & & 0 & 時刻別テー一夕は季節別の特定期間のみ \\
\hline 10 & $\mathrm{O}$ & 0 & & & & 0 & & & & \\
\hline 11 & 0 & 0 & 0 & & 0 & 0 & 0 & & 0 & 時刻別テータは季䇝別の特定期間のみ \\
\hline 12 & 0 & 0 & 0 & & 0 & 0 & 0 & & 0 & 時刻別データは季嚮別の特定期間のみ \\
\hline 13 & 0 & 0 & 0 & 0 & 0 & 0 & 0 & 0 & 0 & 時刻別 $テ$ 一多は8760時間分 \\
\hline 14 & 0 & 0 & 0 & 0 & 0 & 0 & 0 & 0 & 0 & 時刻別 $\vec{r}$ 一夕は8760時間分 \\
\hline 15 & 0 & 0 & & & & 0 & & & & \\
\hline 16 & $\mathrm{O}$ & o & & & & $\mathrm{O}$ & & & & \\
\hline
\end{tabular}

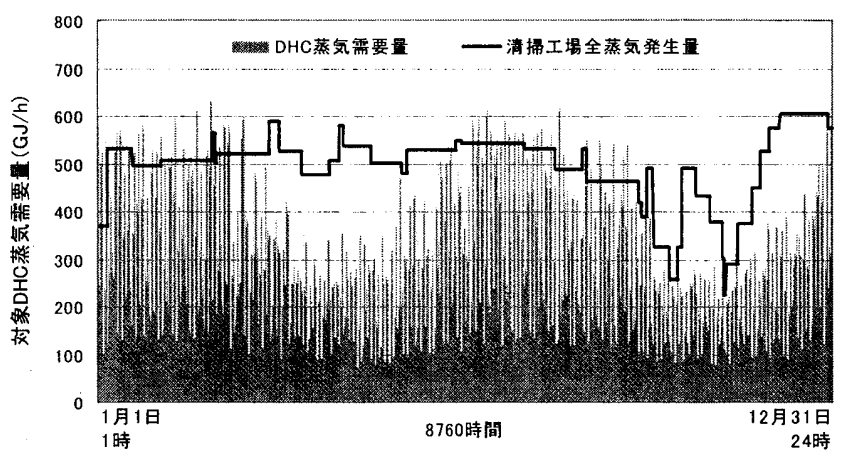

図10 既存DHC蒸気需要量と清掃工場全蒸気発生量

表 5 将来DHC供給エリアの延床面積（仮定）

\begin{tabular}{|c|c|c|c|c|c|c|}
\hline \multirow{2}{*}{$\begin{array}{c}\text { ネットワーク遒管 } \\
\text { からの殐国 }\end{array}$} & \multicolumn{6}{|c|}{ 用途別延休面積 ( $\left(\mathrm{m}^{\prime}\right)$} \\
\hline & 事務所建案物 & |専用商業施設 & 教育文化施設 & 厘生医療施設 & 宿泊·遊興施設 & 住宅施設 \\
\hline $200 \mathrm{~m}$ & $2,885,973$ & $1,229,022$ & 251,492 & 47,967 & 291,493 & $2,015,900$ \\
\hline
\end{tabular}

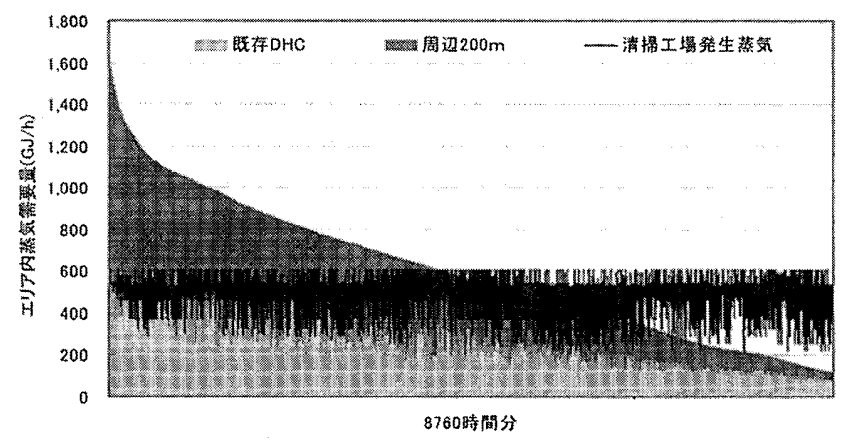

図11 DHC供給エリア蒸気需要量と清掃工場発生蒸気

る。そこで近い将来新設されるであろうDHCプラントも考 慮に入れたトで熱源ネットワークを想定する。将来DHCの 供給エリアとして、地域冷暖昘推進地域を選定する。

地域冷暖房推進地域に該当する地域として、法定容積率 が $400 \%$ 以上の近隣商業地域、商業地域及び準工業地域、都 市計町法により再開発促進地区圳と定められた地域が挙げ られる往6!。

将来DHCの供給エリアは、仮にネットワーク導管（池袋〜 品川）から $200 \mathrm{~m}$ の範䀦に当たる地域泠暖房推進地域（既 你DHC供給エリアを除く）を想定する。そのエリア内の建 物データを抽出し、地区内の建物全てに冷温熱を供給する 
ことを想定し、新設DHCの蒸父需要量を算出する。

将来DHCの供給エリアの延床面積は表5に示す。供給エリ ア内の建物全てに対して冷房・暖房・給湯のための地域熱 供給を行うものとし、各建物の延床面積に熱負荷原単位 ${ }^{25}$ を乗じてエリア内における年間熟需要量を算出した。図 11 にDHC供給エリア（既存DHCと将来DHC）の蒸気需要の累積負 荷曲線を示す。供給先を增やすことによって、清接「場発 生蒸気を有効活用できることがわかる。

\section{4. ごみ焼却熱を活用した熱源ネットワークの評価}

DHC側では、清掃I場の排熱を活用した場合、排熱分の蒸 敂を製造する必要がなくなるため、投入一次エネルギー、 及びその際発生する $\mathrm{C}_{2}$ を削減することが予測できる。

\section{(1) 蒸気有効利用率}

DHCでは、清掃「場の発生蒸気を優先的に利用するものと する。 8760 時間分の有効利用可能な清掃工場蒸気量を合計 した結果を表 6 に示す。有効利用率が増加することが分 かった。

（2）熱供給した場合の一次エネルギーと $\mathrm{CO}_{2}$ 削減効果

清搨匹場側での発電した場合の投入一次エネルギー削減 効果（代替火力発電所）、 $\mathrm{C}_{2}$ 削減効果（代替全電源及び火 力発電所）との差を仮定した熱源ネットワークの省エネ及 び省 $\mathrm{C} 0$ 効果と見なす（表 $6 ） 。$ 供給先を増やすことによっ て投入一次エネルギー及び $0_{2}$ の削減劫果が响:することが 分かった。

\section{5. まとめ}

本研究では、東京都区部の清嵌 $\mathrm{I}$ 場の現状調查を行い、 蒸気発生量、夕ービン投入蒸気量、発電電力量、蒸颌エン タルピ、メンテナンススケジュール、メンテナンス時開の 内訳等の実績データを分析することによって、以トの知見 を得られた。

(1) 東京都区部における全ての清掃 $\mathrm{I}$ 場には発電設備が設 けられており、ごみ焼却熱を利用した発電が行われて いる。清塴工場全体年閏全蒸気発生量のうち、67\%が タービンへ投入され、年間全発電量のうち、55\%が白家 用、45\%が一般電気事業者への売電を行っていることが 分かった。

(2) 現状調查より得られた実績值を用いて、束京都区部清 掃丁場のタービン発電効率は平均 $18 \%$ となる。但し、発 生蒸気全体の利用率は12.6\%に過ぎない。

(3) 発生蒸気を熱供給することによる投入一次エネルギー 及びC $0_{2}$ 削減糼果は大きいことが分かった。発電に比し て、約2.0倍の投入一次エネルギ一削隇効果がある（企 清挤 1 : 場平均)。C 0 , 削減効果は、火力平均 $\mathrm{C} 0$, 排出原単 位を用いると現状の 1.5 倍があり、全電源平均 $\mathrm{C} 0$. 排出原 単位を用いると現状の3.0倍の効果を示す結果となった （全清排上場平均）。

（4）各省研究成果に基づき、東京副都心部（池袋〜品川） において熱源ネットワークを仮定し、清掅「場の発生
表 6 供給エリア拡張時の清掃工場蒸気有効利用率 (仮想値)

\begin{tabular}{|c|c|c|}
\hline 供給エリア範囲 & $\begin{array}{c}0 \mathrm{~m} \\
\text { (既存DHC) }\end{array}$ & $\frac{200 \mathrm{~m}}{\text { (既存DHC+将来DHC) }}$ \\
\hline 蒸気有効利用量( $T J /$ 年) & 2,412 & 3,486 \\
\hline 蒸気有効利用率 $(\%)$ & $55 \%$ & $80 \%$ \\
\hline エネルギ一削減量 (TJ/年) & 1.004 & 2,101 \\
\hline $\mathrm{CO}_{2}$ 削減量 (火力平均) $\left(\mathrm{t}-\mathrm{CO}_{2} /\right.$ 年) & 5,411 & 61,438 \\
\hline $\mathrm{CO}_{2}$ 削減量(全電源平均) $\left(\mathrm{t}-\mathrm{CO}_{2} /\right.$ 年) & 83.829 & 139,855 \\
\hline
\end{tabular}

蒸気を熱供給した場合の投入一次エネルギーと $\mathrm{CO}_{2}$ 削減 効果を検討した。既存DHC供給エリアに対して清掃厂場

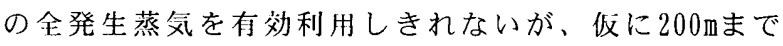
供給エリアの拡張を想定した場合、投入一次エネル

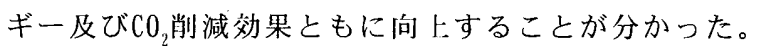

注

注1)エコまちネットワーク整借事業：都市再牛緊急整備地域内におい て、熱導管等の整備話画及び $\mathrm{CO}_{2}$ 削隇量などの整備効果を明示する 都市環境負荷削減プログラムを策定・公表する場合に、以下の施 設整備等に要する費用について補助する。

(1)都沛環境負荷削減プログラム策定に要する費用

(2)都市環境負荷削減プログラムに位置付けられた施設の整储費用 複数の熱供給プラントを速携するための熱導管、

熱交換器及び付帯施被

都汸排熱を処理するための熱導管、熱交換器及び付耑施設 注2)多摩川は平成15年7月1川からのデータである。

注3）場内の蒸気使用量及び場外への熱供給错が少ないため、ここでは 発電電力量からみた発生蒸知の利用率である。

注4) 各種係数

\begin{tabular}{|c|c|c|c|}
\hline \multicolumn{2}{|c|}{ 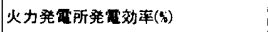 } & 36.6 & 改正少工ネ法(経斎産慕省令第101号)、2004年10月6日） \\
\hline \multicolumn{2}{|c|}{ 都市カスス発䓡量 $\left(\mathrm{MJ} / \mathrm{Nm}^{3}\right)$} & 46.046 & 東京ガス侏木ームページ(2006年2月現在) \\
\hline \multirow{3}{*}{$\mathrm{CO}_{2}$ 排出係数 } & 全電源 $\left(\mathrm{kg}-\mathrm{CO}_{2} / \mathrm{kWh}\right)$ & 0.378 & 「地球温暖化対策の推進に関する法律施行令」、2002年 12月 \\
\hline & 火力 $\left(\mathrm{kg}-\mathrm{CO}_{2} / \mathrm{kWh}\right)$ & 0.69 & 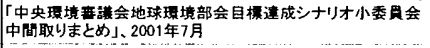 \\
\hline & 都市ガス $\left(\mathrm{kg}-\mathrm{CO}_{2} / \mathrm{m}^{3}\right)$ & 2.36 & 東京ガス珠ホームページ（2006年2月現在） \\
\hline
\end{tabular}

注う)ここでのDHCプラントの熱源システムとしては、COP0.85のボィラ とCOP1.2の吸収冷凍機によるシステムを想堡し、就篮要家として は、食て業務用施設を想定している。また、凝綰水邀り温度を 80 「兄としている。（参照原単位：コンパクトエネルギーシステムの 開発)

注6)東京都地域冷暖房推進に関する指導要網：東京都地域冷暖房推進 に関する指導要網 第 3 条

\section{参考文献}

1) 内田鉄平他: 主要都市における末利用エネルギー活用可能性の検部， 日本建築学会大会学術譜演梗概集，D-1分冊，pp. 553〜 556,1998

2）経済産業省資源エネルギ一庁: 総合資源エネルギー調査会第7回新工 ネルギー部会報告書, 2001.6

3）建設省都市局: 都市熱源ネットワーク，建設少都市易，1997.3

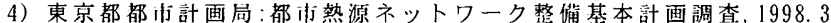

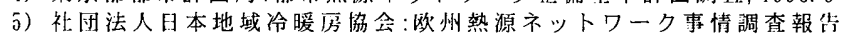
青, 1999. 4

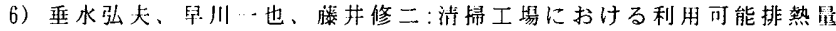
の推定 (その1) 都书排熱の地域冷暖房への導入に関する研究，日本建 築学会計画系論文報华集符 347 号, pp. 11 20,1985.1

7）垂水弘夫、藤井修二、久保猛志、卓川… 清掃工場を熱源とする 地域熱供給閔題の梌㶦 (その2) 都书排熱の地域冷暖房への導入に関 する研究，日本建築学会計画系袷文報售集第378号，pp. 28 $37,1987.8$

8）財用法人エンジニアリング振興協会: 宫温水広域ネットワークシス テムの具体化に関する調杳研究，2000.3

9）财性法人エンジニアリング拨興協会:尚温水去域ネットワークシス テムの具体化に関する調查破究。2001.3

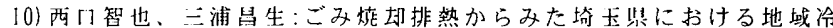
暖房導入の可能性，日本建築学会大会学術請演梗概集，pp.667 $668,1997.9$

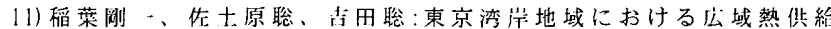
ネットワークの導入効果に関する考察，11本建築学会大会学術满演 梗概集，pp.719〜 720,2000.9

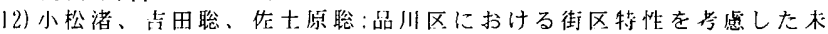


利用エネルギーの份効活用システムの検討に関する研究，日本建築 学会大会学術講演梗概集, pp. 721 722,2000.9

13)勛団法人ヒートホンプ・蓄熱センター:広域エネルギー利用ネット ワークシステム開発エネルギーシステム設計技術の研究『エコ・エ ネ都市のシステム化研究』平成 12 年度成果報华㫪, 2001. 3

14)財団法人临エネルギーセンター:東京地区におけるトータルネット ワークシステムの評洒研究, 2001.3

15）新エネルギー・産業技術総合開発機構: 法域エネルギ一利用ネット ワークシステム（エコ・エネルギー都柿プロジェクト）,2002.3

16）日本罟境技研株式会社: 東京・名古屋地区における広域熱供給ネッ トワークケーススタディ, 2002.3

17) 国土交通省都市・地域整備局:既成行街地に打ける面的整借事業に 係るエネルギーの有効利用方策検討調查, 2006.3

18) 東京都二十三区清掃協議会: 23 区清掃とリサイクル2005, 東京都二十 三区清掃協議会, 2005.9

19)財団法人廃莱物研究財团:ごみ焼却施設電子台帳及びデータベース 平成 15 年版, 2005.4

20)石川祜昭:ごみ燅却排熱のおもしろ科学，理工図畫，1997.6

21) 岡田坦郎: 地中埋設管の損失熱量と温度降下の概略計算法, 1972.5

22)社団法人日本地域冷暖房協会:地域冷暖房技術手引書，社闭法人日本 地域冷暖房協会，改訂新版，2002.11

23）社団法人日本熱供給事業協会:平成 16 年度版熱供給事業便覧，社时法 人日本熱供給事業協会, 2005.12

24) 東京都都市整備局: 東京都に招ける市街地再開発事業の概要, 東京都 都书整備局, 2005.11

25) 尾岛俊雄研究室: 建築の光熱水原単位, 早稲田大学出版部, 1995.6

（2006年10月10日原稿受理，2007年 5 月 25 日採用決定） 